\title{
Medhya Rasayanas in Brain Function and Disease
}

\section{Suman Ray ${ }^{1 *}$ and Asim Ray ${ }^{2}$}

${ }^{1}$ CSIR-National Institute of Science Technology and Development Studies (CSIR-NISTADS), Pusa Gate, KS Krishnan Marg, New Delhi, India ${ }^{2}$ SRM University, NCR Campus, Delhi, India

\section{Abstract}

Ayurveda (Sanskrit word meaning "the scripture for longevity") represents an ancient system of traditional medicine prevalent in India about 5000 years old. Rasayana concept of Ayurveda is believed to be useful to overcome challenging diseases to modern medicine i.e., regeneration of tissues after the disease condition like osteoarthritis, age related macular degeneration (AMD), Alzheimer's and Parkinsons disease, injuries, trauma, heart attack, stroke etc. Neurological and psychiatric disorders are generally associated with loss of memory, cognitive deficits, impaired mental function etc. The 'medhya rasayanas' are known to be beneficial to improve the intellectual e.g., mandukparni swaras, yashtimadhu churna with ksheer, guduchi swaras, and shankhapushpi kalka. Medhya Rasayana drugs are used for prevention and treatment of mental disorders of all the age groups. These drugs promote the Intellect (Dhi) Retention power (Dhriti), memory (Smriti). Mood disorders are known to be associated with considerable burden of disease, suicides, physical comorbidities, high economic costs, and poor quality of life. Therefore, it has become a major public health problem today. Unfortunately modern medicine based psychoactive drugs have met with limited success in treatment of various neurological and psychiatric disorders due to multi-factorial nature of these diseases. This review discusses about Medhya Rasayanas as a great player for prevention and management of age related cognitive decline.
\end{abstract}

Keywords: Ayurveda; Medhya rasayanas; Cognition; Degeneration; Mental disorders

\section{Ayurvedic Approach of Disease Prevention}

Ayurveda is considered the Upaveda of Atharva Veda, being the oldest recorded wisdom of the earth. Rasayana has been considered as a form of rejuvenative recipes, dietary regimen and a special health promoting conduct and behaviour i.e., Achara-Rasayana Arvid This therapy helps the individual to attain longevity, memory, intelligence, freedom from disorder, youthful age, excellence of luster, complexion and voice, optimum strength of physique and sense organs, successful words, respectability and brilliance. Ayurveda is believed to cure human diseases through establishment of equilibrium in the different elements of human life, the body, the mind, the intellect and the soul [1]. Ancient Ayurvedic approach of disease prevention involves therapeutic measures to arrest/delay ageing and rejuvenating whole functional dynamics of the body system. According to Ayurveda, the homeostasis of the body is maintained by Doshas that regulate all the metabolic processes-(a) Vata-regulates the catabolic activity (tissue wear and tear) (b) Kapha-stimulates synthesis of newer tissues (c) Pitta-governs the process of nutrients assimilation into tissues [2]. The revitalization and rejuvenation approach in Ayurveda is known as the 'Rasayan chikitsa' (rejuvenation therapy), one of the eight specialized branches of Ayurveda. It aims enhancement in strength, immunity, ojus, vitality, will power and determination of the body, longevity, memory, intelligence, excellence of luster, complexion and voice, optimum strength of physique and sense organs. Ayurvedic approach of treatment schedule of psychiatric disease is divided into three main categories as described in Figure 1.

Ayurveda has described various kinds of mental Disorders [3]:

1. Unmada (Insanity)

2. Apasmara (Epilepsy)

3. Atattvaabhinivesha (Obsessive Disorders)

4. Bhaya (Fear)

5. Harsha (Excitation)

6. Shoka (Grief)

7. Udvega (Anxiety)

8. Avasada (Depression)
Considering the effects of drugs on body and how to maintain proper health, acharya Charaka has classified all the drugs into three groups [3]:

1. Dosha Prashamana- which pacifies the vitiated doshas

2. Dhatu Pradushana- which vitiates Dhatus

3. Svasthavrittakara- which maintains the proper health

According to Ayurvedic approach, Rasayana agents are considered to promote nutrition through the following modes [4]:

1. Direct enrichment of the nutritional quality of Rasa (nutritional plasma)- Satavari, milk and Ghee.

2. Promoting nutrition through improving Agni (digestion and metabolism) as Bhallataka, Pippali.

3. Promoting the competence of Srotas (microcirculatory channels in the body) as Guggulu etc.

\section{Rasayana Chikitsa}

According to Acharya Charak, equilibrium of Agni of Dhatu, Vayu, and Srotas are essential factors for maintaining normal strength, color and longevity of the body. In Ayurveda, Medhya is described in broad way. Medhya comprises of all the three mental faculties- Dhee, Dhriti and Smriti and these are interrelated with each other [3]. Medhya can also be subdivided into the following faculties:

1. Grahanshakti (Power of Grasping)

*Corresponding author: Dr. Suman Ray, Scientist, CSIR-National Institute of Science Technology and Development Studies (CSIR-NISTADS), Pusa Gate, K.S. Krishnan Marg, New Delhi-110012, India, Tel: +911125843127; Fax: +911125846640; E-mail: sumanitrc@gmail.com

Received October 30, 2015; Accepted December 02, 2015; Published December 07, 2015

Citation: Ray S, Ray A (2015) Medhya Rasayanas in Brain Function and Disease. Med chem 5: 505-511. doi: 10.4172/2161-0444.1000309

Copyright: (c) 2015 Ray S, et al. This is an open-access article distributed under the terms of the Creative Commons Attribution License, which permits unrestricted use, distribution, and reproduction in any medium, provided the original author and source are credited. 


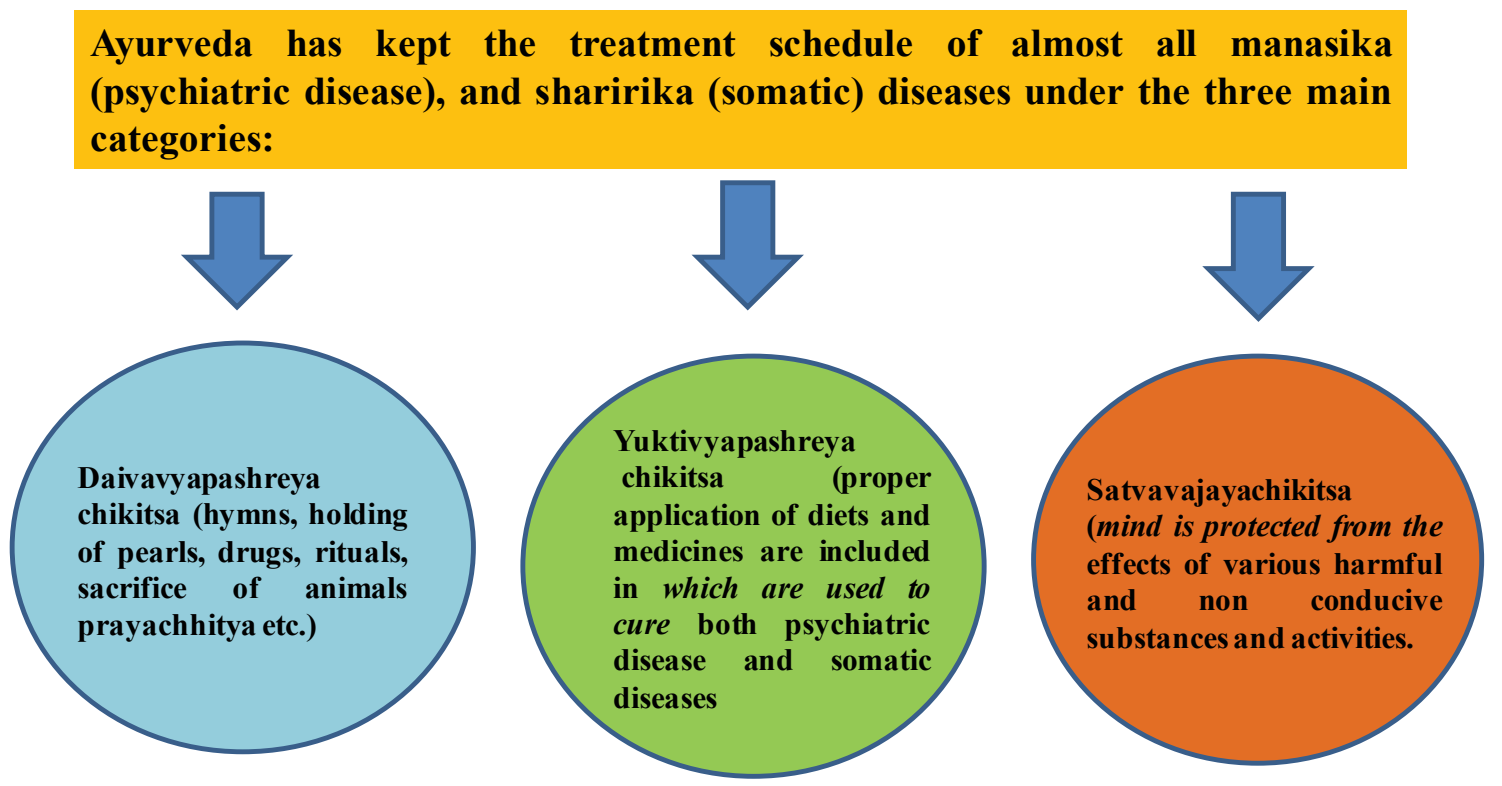

Figure 1: Ayurvedic approach of treatment schedule of psychiatric disease is divided into three main categories.

2. Dharana shakti (Power of Retention)

3. Vivekshakti (Power of Discrimination)

4. Smriti (Power of recollection)

The aim of Rasayana Chikitsa is to nourish blood, lymph, flesh, adipose tissue and semen. This prevents the individual from chronic degenerative diseases. The therapy influences the fundamental aspect of body viz., Dhatus, Agni, Srotansi and Ojus [4]. In Rasayana therapy, the Bheshja (medicine) is divided into two types:

$\alpha$. Swasthasyaurjaskara-toning up the health of a healthy person

$\beta$. Kinchit Artasya Rognut-treating the ailments of the patients

\section{Rasayana Drugs}

As per Acharya Charak, Rasayanais defined as the means of achieving the finest quality of rasadidhatus (body tissues) where it increases life span, improves medhya (intelligence), cures disease, stabilizes youthfulness, improves luster, complexion, voice and makes body and senses strong and healthy etc. Rasayana drugs acts as-

a. Immunomodulator- By augmenting or reducing the ability of the immune system.

b. Adaptogen- Increases the ability of an organism to adapt to environmental factors e.g., Ashwagandha, Tulsi, haridra, Pippali, Amalaki, Guduchi, shatavari.

c. Antioxidant- Circumvent the damage caused by oxygen free radical.

d. Nootropic- Promote intelligence and functions of brain e.g., Medhya Rasayana drugs (namely-Mandookparni, Guduchi, Yashtimadhu and Shankhpushpi).

\section{Types of Rasayana (Rejuvenation) therapy [5]}

According to achievable outcome- Rasayana is of three types:

1. Naimittika rasayana (nimitt-Sanskrit for "cause") is also known as Rogapaharan or Curative type of Rasayan. It is used to combat or balance a specific cause responsible for the disease in the body. Few examples include Dhatri rasayana, Mandookaparni rasayana, Brahmi rasayana, and Triphala rasayana.

2. Ajasrika rasayana is used to maintain good health and improve the quality of life through a healthy lifestyle, diet, or exercise. It is also called as Vayasthapan Rasayan.

3. Kamya rasayana- This is described as to fulfill a wish or desire or to serve a special purpose (kama - desire). It is of four types:

$\alpha$. Prana Kamya- best quality of prana (life energy) in the body.

$\beta$. Medhya Kamya- enhancing the memory and intellect. e.g., Shankhapushpi Rasayan.

$\chi$. Ayush Kamya- increasing longevity.

$\delta$. Chakshu Kamya- maintaining healthy eyes.

According to mode of Administration- It is of two types:

1. Kutipraveshika (kuti-cottage, pravesha-enter)- It is an indoor management in which the person lives in a specially prepared cottage for a long period while taking various rasayana herbs.

2. Vatatapika- Where "vata" means air, and "atapa" means heat or sun (good for people who are engaged in everyday life activities). It is an outdoor management and involves taking rasayana, while a person remains exposed to air and heat. It includes Chyavanaprasha, Brahma rasayana Shilajitu rasayana, Amalaki rasayana, Haritaki rasayana, Pippali rasayana, Lohadi rasayana and Loha shilajitu rasayana. A total of 63 combinations of various rejuvenation formulae are described in the Charaka samhita.

According to modalities- It is of three types:

1. Achar Rasayan (Behavioural modalities)- describes a type of rasayana for psychological and spiritual health. It focuses on the body, mind, and soul, Ayurveda also.

2. Ahar Rasayan (Dietary modalities)- includes rules relating to eating, sleeping, and celibacy create rejuvenation in a person, 
following a sattvik diet and life style, speaking the truth, practicing non-violence, living in harmony with the nature, following social ethics and conducts, are all included under this category of rasayana.

3. Dravya (Aushadha) Rasayan- includes some herb and food types that are indeed beneficial for the optimum functioning of the body as well as the brain.

\section{What is Medhya Rasayanas?}

The word 'medhya rasayanas', have been derived from the Sanskrit words 'medhya', meaning intellect or cognition, and 'rasayana', meaning 'rejuvenation. The medicinal plants in the Ayurvedic system are classed as brain tonics or rejuvenators. Earlier reports indicate that these plants are used both in herbal and conventional medicine and offer benefits that pharmaceutical drugs lack [6]. Neurological and psychiatric disorders are generally associated with loss of memory, cognitive deficits, impaired mental function etc. The 'medhya rasayanas' are known to be beneficial to improve the intellectual e.g., mandukparni swaras, yashtimadhu churna with ksheer, guduchi swaras, and shankhapushpi kalka. Table 1 describes about drugs having the Medhya Rasayana property.

Medhya Rasayana is a group of 4 medicinal plants (Figure 2) that can be used singly or in combinations [7]:

1. Mandukaparni (Centella asiatica Linn.)-act on behaviour besides being neuroprotectives brain growth promoter, inhibits the memory impairment induced by scopolamine through the inhibition of AChE.

2. Yastimadhu (Glycirrhiza glabra Linn.)-it increases the circulation into the CNS system, improves learning and memory on scopolamine induced dementia.

3. Guduchi (Tinospora cordifolia (Wild) Miers)- possess learning and memory enhancing, antioxidant, and anti-stress action, enhances the cognition in normal and cognition deficits animals in behavioural test. It is useful for treatment of bhrama (Vertigo), in improving behavior disorders, mental deficit and IQ levels [8].

4. Shankhapushpi (Convolvulus leuricaulis Chois)-effective in hittodvega (anxiety disorders), reverses the social isolation stress- induced prolongation of onset and decrease in pentobarbitoneinduced sleep, increased total motor activity and stress-induced antinociception in experimental model.

The formulation of Medhya Rasayana drugs are of two types:

1. Shita Virya and Madhura Vipaka- it promotes kapha and enhances "Dharana Karma" (i.e., retention of cognition) e.g., Yastimadhu, Bramhi, Sankhpushpi etc.

2. Ushna Virya and Tikta Rasa- it promotes pitta and enhances Grahana and Smarana (i.e., grasping power and Memory) e.g., Guduchi, Vacha, Jyotishmati etc.

Medhya drugs act at different levels [4]-

$\alpha$. at level of Rasa

$\beta$. act by stimulating and improving the function of Agni

$\chi$. improve circulation of Rasa by opening and cleaning the micro channel and thus improving Medhya function.

\section{Medhya rasayanas in neuroprotection}

Medhyarasayana drugs play an essential role in the treatment of psychiatric and psychosomatic diseases. The mode of this therapy involves the individual to attain sedation, calmness, tranquility or a stimulation of activities of brain [3]. Based on the experimental and clinical research, it is known that these drugs have varying degree of psychotropic action and are known to possess antidepressant, sedative and tranquilizing action. Medhya Rasayana drugs are used for prevention and treatment of mental disorders of all the age groups. These drugs promote the Intellect (Dhi) Retention power (Dhriti), memory (Smriti). In fact they produce Nueuronutrient effect by improving cerebral metabolism [9]. Medhya Rasayana drugs are known to have specific effect on mental performance by promoting the functions of "Buddhi" and "Manas" by correcting the disturbances of "Rajas" and "Tamas" [9]. This helps the mental patient to get relieve from stress, anxiety and depression. Medhya Rasayana in aging brain is described in Table 2.

Earlier reports indicate that 'Rasayan drugs' could be used in stem cell therapy. This may be beneficial to overcome challenging diseases to modern medicine i.e., regeneration of tissues after the disease

\begin{tabular}{|c|c|c|c|c|c|}
\hline \multirow[t]{2}{*}{ Medhya drugs } & \multirow[t]{2}{*}{ Synonyms } & \multicolumn{4}{|c|}{ Properties } \\
\hline & & Rasa & Guna & Virya & Vipaka \\
\hline $\begin{array}{l}\text { Mandukaparni (Centella asiatica Linn. } \\
\text { Family - Umbelliferae) }\end{array}$ & $\begin{array}{c}\text { Manduki, Twastri, Divya, Mahausadhi. Dosha karma - Kapha-Pitta } \\
\text { shamak. }\end{array}$ & Tikta & Laghu & Sita & Madhur \\
\hline $\begin{array}{l}\text { Yastimadhu (Glycyrrhiza glabra Linn., } \\
\text { Family - Fabaceae) }\end{array}$ & Yas-timadhuk, Klitaka. Dosha karma - Vata- pitta shamak & Madhur & Guru, Snigdha & Sita & Madhur \\
\hline $\begin{array}{l}\text { Guduchi (Tinospora cordifolia Willd. } \\
\text { Miers, Family - Menispermaceae) }\end{array}$ & $\begin{array}{c}\text { Amrita, Madhuparni, Chinnamula, Cakra-lakshanika, Amrita-valli, } \\
\text { Chinna, Chin-nodhbhava, Vatsadani, Jivanti, Tantrika, Soma, Somavalli, } \\
\text { Kundali, Dheera, Vi-shalya, Rasayani, Candrahasa, Vayastha, Mandali, } \\
\text { Deva-nirmita, Dosha karma - Tri-dosha shamak }\end{array}$ & Tikta, Kasaya & Guru, Snigdha & Usna & Madhur \\
\hline $\begin{array}{l}\text { Shankhapushpi (Convolvulus pleuricaulis } \\
\text { Chois. Family - Convolvula-ceae): }\end{array}$ & Ksheerpushpi, Mangalyakusuma. Dosha karma - Vata- pitta shamak & Tikta & $\begin{array}{l}\text { Snigdha, } \\
\text { Picchil }\end{array}$ & Sita & Madhur \\
\hline $\begin{array}{l}\text { Aindri (Bacopa monniera Linn. Family - } \\
\text { Scrophulariaceae) }\end{array}$ & & Tikta & Laghu & Usna & Katu \\
\hline $\begin{array}{l}\text { Jyothishmati (Celastrus panniculata } \\
\text { Willd. Family - Celastraceae): }\end{array}$ & $\begin{array}{c}\text { Katabhi, Jyotishka, Kanguni, Paravatpadi, Pinya, Lata, Kakundani, Mal- } \\
\text { kangani. Dosha karma - Vata-kapha sha-mak }\end{array}$ & Katu, Tikta & Tikshna & Usna & Katu \\
\hline $\begin{array}{l}\text { Kushmanda (Benincasa hispida Thunb. } \\
\text { Cogn. Family - Cucurbitaceae) }\end{array}$ & Puspaphala, Pitapushpa, Brihatphala. Dosha karma - Pitta shamak & Madhur & $\begin{array}{l}\text { Laghu, } \\
\text { Snigdha }\end{array}$ & Sita & Madhur \\
\hline $\begin{array}{c}\text { Vacha (Acorus calamus Linn., Family - } \\
\text { Araceae) }\end{array}$ & $\begin{array}{c}\text { Vacha, Ugragandha, Sadhgrantha, Golomi, Satparvika, Khudra-patri, } \\
\text { Mangalya, Jatila, Ugra and Lomasha, Dosha karma - Kapha-Vata } \\
\text { shamak8 }\end{array}$ & Katu, Tikta & $\begin{array}{l}\text { Laghu, } \\
\text { Tikshna }\end{array}$ & Usna & Katu \\
\hline $\begin{array}{l}\text { Jatamamsi (Nardostachys jatamansi DC., } \\
\text { Family - Valerianaceae) }\end{array}$ & $\begin{array}{c}\text { Bhutjata, Jatila, Tapas-vini and Mansi. Dosha karma - TriDosha } \\
\text { shamak }\end{array}$ & $\begin{array}{l}\text { Tikta, Kasaya } \\
\quad \text { Madhur }\end{array}$ & $\begin{array}{l}\text { Laghu, } \\
\text { Snigdha }\end{array}$ & Sita & Katu \\
\hline
\end{tabular}

Table 1: Drugs having the Medhya Rasayana property [34]. 


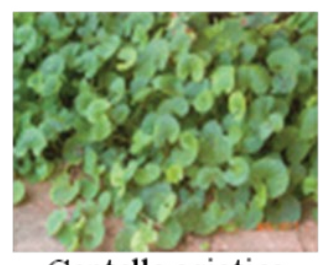

Centella asiatica

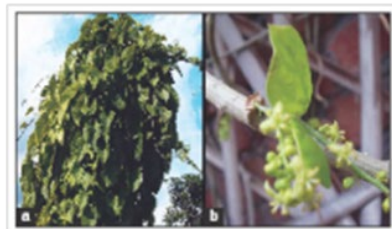

Tinospora cor difolias

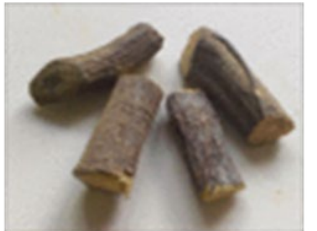

Glycirrhiza glabra

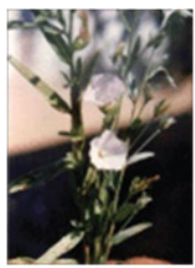

Convolvulus pluricaulis
Figure 2: Medhya Rasayana is a group of 4 medicinal plants

\begin{tabular}{|c|c|c|}
\hline S No & Example & Role in aging brain \\
\hline 1. & $\begin{array}{l}\text { Yashtimadhu } \\
\text { (Glycyrrhiza glabra) }\end{array}$ & $\begin{array}{l}\text { Spatial learning and passive avoidance, } \\
\text { preliminary free radical scavenging, cerebral } \\
\text { ischemia and antioxidant capacity towards LDL } \\
\text { oxidation. }\end{array}$ \\
\hline 2. & $\begin{array}{l}\text { Guduchi (Tinospora } \\
\text { cordifolia) }\end{array}$ & $\begin{array}{l}\text { Strong free radical scavenging properties against } \\
\text { reactive oxygen and nitrogen species diminishing } \\
\text { the expression of iNOS gene, reduction in } \\
\text { thiobarbituric acid reactive substances and an } \\
\text { increase in reduced glutathione catalase and } \\
\text { superoxide dismutase (anti-oxidant) }\end{array}$ \\
\hline 3. & $\begin{array}{l}\text { Shankhapushpi } \\
\text { (Convolvulus } \\
\text { pluricaulis) }\end{array}$ & $\begin{array}{l}\text { Anxiolytic, memory enhancing and mood elevating } \\
\text { effect, retard brain aging, help in regeneration } \\
\text { of brain cells and in Dendritic arborization which } \\
\text { is the neuronal basis for improved learning and } \\
\text { memory, increase in AGhE activity in CA1 with AS } \\
\text { and CA3 }\end{array}$ \\
\hline 4. & $\begin{array}{l}\text { Mandukaparni } \\
\text { (Centella asciatica) }\end{array}$ & $\begin{array}{l}\text { Neuronal dendritic growth stimulating } \\
\text { property, effective in reducing brain regional } \\
\text { lipidperoxidation (LPO) and protein carbonyl } \\
\text { (PCO) levels and in increasing anti-oxidant status, } \\
\text { improve the altered levels of neurotransmitters } \\
\text { such as 5HT, acetylcholine, epinephrine, nor- } \\
\text { epinephrine, GABA (gamma-aminobutyric acid) } \\
\text { and Glutamate, improve the mental ability and } \\
\text { fatigability of subjects under stress, inhibit the } \\
\text { formation of beta amyloid plaques owing to the } \\
\text { oxidative stress and activation of glial cells and } \\
\text { thereby delay neuronal apoptosis. }\end{array}$ \\
\hline 5. & $\begin{array}{l}\text { Brahmi } \\
\text { (Bacopa monnieri) }\end{array}$ & $\begin{array}{l}\text { Positive implications for improved } \\
\text { neurotransmission and repair of damaged neurons } \\
\text { via enhanced regeneration of nerve synapses } \\
\text { via changes in the hippocampus, cerebral } \\
\text { cortex (areas critical to memory function) and } \\
\text { hypothalamus regions of the brain. }\end{array}$ \\
\hline 6. & $\begin{array}{l}\text { Ashwagandha } \\
\text { (Withania Somnifera) }\end{array}$ & $\begin{array}{l}\text { GABA-like activity, owing to its anxiolytic effect, } \\
\text { increase in the levels of three natural antioxidants } \\
\text { superoxide dismutase, catalase and glutathione } \\
\text { peroxidase. }\end{array}$ \\
\hline 7. & $\begin{array}{l}\text { Kapikachu } \\
\text { (Mucuna Pruriens) }\end{array}$ & $\begin{array}{l}\text { Contain significant quantity of L-Dopa which could } \\
\text { be the basis for its anti- Parkinsonism effect. }\end{array}$ \\
\hline 8. & $\begin{array}{l}\text { Jyotishmati } \\
\text { (Celastrus paniculata) } \\
\text { and Tagara (Valeriana } \\
\text { wallichii) }\end{array}$ & Role in brain and memory disorders in the elderly. \\
\hline
\end{tabular}

Table 2: Medhya Rasayana in aging brain [35].

condition like osteoarthritis, age related macular degeneration (AMD), Alzheimer's and Parkinsons disease, injuries, trauma, heart attack, stroke etc [10]. Rasayana concept of Ayurveda has been correlated with tissue regeneration and cell renewal and specific rasayana is known to stimulate and nourish respective dhatus or tissues [2]. For example, Medhya Rasayana for the brain, Hridya Rasayana for the heart, Twachy Rasayana for the skin, and Chakshusya Rasayana for the eyes. Role of 'medhya drugs' in neuronal stem cells differentiation is also described earlier [2]. Ayurveda have been described to provide a list of herbs known for nootropic activity having multi-dimensional utility in various conditions [7]. Medhya Rasayana drugs and its mode of action is described in Table 3.

\section{Mandukaparni (Centella asiatica Linn.)}

Earlier studies have reported ameliorating effect of CE on learning and memory impairment induced by either transient bilateral common carotid arteries occlusion (T2 VO) in mice [11]. Centella asiatica plays a significant role in improving cognition and memory. One of the major etiological factors implicated in Parkinson's disease (PD) is $\alpha$-Synuclein aggregation. Interestingly evidences also indicate that the aqueous extract of Centella asiatica (CA) inhibit the formation of oligomer to aggregates and stimulate the disintegration of the preformed fibrils [12]. Other investigators have shown the relevance of Centella asiatica to its anti-oxidant and anti-apoptotic mechanisms. Exploration of the neuroprotective effect of Centella asiatica on chronic aluminum exposure induced mitochondrial enzyme alteration, oxidative stress, apoptosis and cognitive dysfunction in rat have shown its multiprotective effect against aluminium induced neurotoxicity [13]. Administration of Centella asiatica showed improved memory performance, oxidative defense decreased aluminum concentration, caspase-3, acetylcholinestrease activity and reversal of mitochondrial enzyme activity as compared to aluminum-treated animals [13]. The significance of Centella asiatica as a neuroprotective agent have already been used traditionally since decades in ayurvedic medicine [14]. Various evidences have reported its neuroprotective potential by different modes of action such as enzyme inhibition, prevention of amyloid plaque formation in Alzheimer's disease, dopamine neurotoxicity in Parkinson's disease, and decreasing oxidative stress [14]. Asiatic acid (AA), a pentacyclic triterpene in Centella asiatica, possess neuroprotective effects both in vitro and in vivo. This was shown to attenuate glutamate-induced cognitive deficits of mice and protects SH-SY5Y cells against glutamate-induced apoptosis in vitro [15].

\section{Yastimadhu (Glycirrhiza glabra Linn.)}

Glycyrrhizin (GL) is a triterpene present in the roots and rhizomes of licorice (Glycyrrhiza glabra) [16]. It is found to have neuroprotective effect in the kainic acid induced neuronal cell death in mouse [16]. This is mediated via suppression of gliosis and induction of proinflammatory markers (COX-2, iNOS, and TNF- $\alpha$ ). The anti-convulsant potential of aqueous and ethanol extract of Glycyrrhiza glabra (AEGG and EEGG) and its action on markers of oxidant stress is shown in pentylenetetrazole (PTZ)-induced seizure in albino rats [17]. Similarly others have also shown neuroprotective effects of glycyrrhizin (GL) in the postischemic rat brain after middle cerebral artery occlusion (MCAO). This mechanism involves its anti-inflammatory, anti-excitotoxic, and antioxidative effects and in particular, it exerts anti-inflammatory effect [18]. In addition, 2,2',4'-trihydroxychalcone from Glycyrrhiza glabra has been shown as a new specific beta-site amyloid precursor protein (APP)-cleaving enzyme 1 (BACE1) inhibitor that efficiently ameliorates memory impairment in mice [19]. Glabridin, isolated from the roots of Glycyrrhiza glabra is also a promising candidate on learning and memory in mice [20]. Other findings indicate that glabridin, a major flavonoid of Glycyrrhiza glabra (licorice) has a neuroprotective effect via modulation of multiple pathways associated with apoptosis [21]. Antidepressant-like activity of Glycyrrhiza glabra is demonstrated in 


\begin{tabular}{|c|c|c|c|}
\hline S No & Medhya Rasayana drugs & Mode of action & Reference \\
\hline 1 & 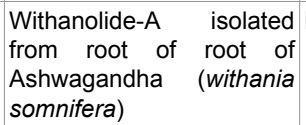 & Neuritic regeneration, synaptic reconstruction, axon extension dendrite extension synaptogenesis memory improvement & {$[36,37]$} \\
\hline 2 & $\begin{array}{l}\text { Withanolide IV } \\
\text { (Withania somnifera) }\end{array}$ & Axon extension dendrite extension synaptogenesis memory improvement & [37] \\
\hline 3 & Withanolide IV & Axon extension dendrite extension synaptogenesis memory improvement & [37] \\
\hline 4 & $\begin{array}{l}\text { Bramhi } \\
\text { (Bacopa monnieri Linn) }\end{array}$ & $\begin{array}{l}\text { Memory enhancement, cognitive function, Reduce amyloid levels in PSAPP mice, effect on cholinergic system, prevent } \\
\text { aluminium neurotoxicity i.e., protect brain from oxidative damage resulting from aluminium toxicity. }\end{array}$ & [38-40] \\
\hline 5 & $\begin{array}{l}\text { Sankhapushpi } \\
\text { (Convolvulus pluricaulis) }\end{array}$ & Anxiolytic and memory enhancing, mood elevating, retard brain aging & [41] \\
\hline 6 & $\begin{array}{l}\text { Mandukaparni } \\
\text { (Centella asiatica) }\end{array}$ & $\begin{array}{l}\text { Useful in treating mental retardation (improvement in performance IQ), Social Quotient, immediate memory span } \\
\text { and reaction time, asiatic acid (AA), a pentacyclic triterpene in Centella asiatica- attenuates glutamate-induced } \\
\text { cognitive deficits of mice and protects SH-SY5Y cells against glutamate-induced apoptosis in-vitro, influence the } \\
\text { neuronal morphology and promote the higher brain function of juvenile and young adult mice, cognitive enhancement, } \\
\text { prevent oxidative stress, enhance neuronal dendrites, dendritic growth in the hippocampal CA3 neurons in adult rats. } \\
\text { antidepressant activity. }\end{array}$ & {$[1,42-45]$} \\
\hline 7 & $\begin{array}{l}\text { Guduchi } \\
\text { (Tinospora cordifolia) }\end{array}$ & $\begin{array}{l}\text { Enhanced verbal learning and memory and logical memory (of immediate and short term type), enhances cognition } \\
\text { (learning and memory) in normal rats and cyclosporine induced memory deficit, anti-stress, anti-depressant and } \\
\text { anxiolytic properties, improvement in sensile memory impairment }\end{array}$ & [46-48] \\
\hline 8 & $\begin{array}{l}\text { Ashwagandha } \\
\text { (Withania somnifera) }\end{array}$ & $\begin{array}{l}\text { Mood stabilizer in clinical conditions of anxiety and depression., clearance and reverses the behavioral deficits and } \\
\text { pathology seen in Alzheimer's disease models. }\end{array}$ & {$[49,50]$} \\
\hline 9 & $\begin{array}{l}\text { Jyothismati } \\
\text { (Celastrus paniculatus) }\end{array}$ & $\begin{array}{l}\text { Affects learning and recall of memory, significant decrease in the AChE activity assayed from hypothalamus, frontal } \\
\text { cortex and hippocampus of the rat brain treated with } 400 \mathrm{mg} / \mathrm{kg} \text { body weight. With CP oil i.e., Jyothismati oil from seeds } \\
\text { of Celastrus paniculatus (CP)) }\end{array}$ & {$[51,52]$} \\
\hline 10 & $\begin{array}{l}\text { Vidanga } \\
\text { (Embelia ribes) }\end{array}$ & $\begin{array}{l}\text { Defence against MCAO- induced focal cerebral ischemia in rats and exhibits neuroprotective activity, useful adjunct in } \\
\text { the treatment of stroke. }\end{array}$ & {$[53,54]$} \\
\hline 11 & $\begin{array}{l}\text { Kushmanda Ghrita } \\
\text { (Benincasa hispida) }\end{array}$ & Increased immediate memory, possess antidepressant activity & [55] \\
\hline
\end{tabular}

Table 3: Medhya Rasayana drugs and its mode of action.

mouse models of immobility tests. This is mediated by increase of brain norepinephrine and dopamine, but not by increase of serotonin [22]. Memory-strengthening activity of Glycyrrhiza glabra in exteroceptive and interoceptive behavioural models of memory is also shown by other investigators [23]. The beneficial effect on learning and memory by Glycyrrhiza glabra (popularly known as liquorice) in mouse brain is due to facilitation of cholinergic-transmission also known [24].

\section{Guduchi (Tinospora cordifolia (Wild) Miers)}

The neuroprotective activity of ethanol extract of Tinospora cordifolia aerial parts have been shown in a study involving 6-hydroxy dopamine (6-OHDA) lesion rat model of Parkinson's disease (PD) [25]. Evidence also exists for aqueous ethanolic extract of Tinospora cordifolia playing a role for differentiation based therapy of glioblastomas [26]. Involvement of Monoaminergic and GABAergic Systems in Antidepressant-like Activity of Tinospora cordifolia is shown in a study involving mouse model of depression using tail suspension test and forced swim test [27]. Another study showed the neuroprotective activity of Tinospora cordifolia involves modulation of the antioxidant system in rat hippocampal slices subjected to oxygen glucose deprivation [28]. Tinospora cordifolia may also play an effective role against ischemic brain damage as it attenuate oxidative stress mediated cell injury during oxygen-glucose deprivation (OGD) in rat hippocampal slices [28].

\section{Shankhapushpi (Convolvulus pluricaulis Chois)}

This drug is known for its action on boosting memory and improving intellect and beneficial for brain disorders like epilepsy. It consists of whole plant of Convolvulus pluricaulis choisy (CP, Convulvulaceae). Shankhapushpi is found to be effective in anxiety, neurosis and used in cerebral abnormalities, insomnia, and serve as wonderful nervine tonic and memory invigorator [29]. Shankhapushpi enhances memory function due to its Antioxidant and Acetylcholinesterase Inhibitory
Properties [30]. Investigators have shown neuroprotective effects of aqueous extract from Convolvulus pluricaulis (CP) against aluminium chloride induced neurotoxicity in rat cerebral cortex [31]. Evidences of antioxidant and anticonvulsant activity of Shankhapushpi is also demonstrated by earlier studies [32]. Earlier evidences have demonstrated the potential of Convolvulus pluricaulis (CP) to attenuate scopolamine $(2 \mathrm{mg} / \mathrm{kg}$, i.p.) induced increased protein and mRNA levels of tau, amyloid precursor protein $(A \beta P P)$, amyloid $\beta(A \beta)$ levels and histopathological changes in rat cerebral cortex [33-55].

\section{Concluding Remarks}

It is very unfortunate that in spite of advancements in modern medicine today its success is very limited in context with neurological and psychiatric disorders due to multi-factorial nature of these diseases. Therefore, the concept of modern medicine based therapy for treatment of such patients may be more effective when based on psychoactive drugs. Hence, the need to explore medicinal plants globally for improving cognitive function owing to their less adverse effects is must today so as to overcome the cognitive deficit diseases.

\section{Acknowledgements}

The authors sincerely thank Director CSIR- National Institute of Science Technology And Development Studies (CSIR-NISTADS), New Delhi for constant support in completing this manuscript.

\section{References}

1. Ven Murthy MR, Ranjekar PK, Ramassamy C, Deshpande M (2010) Scientific basis for the use of Indian ayurvedic medicinal plants in the treatment of neurodegenerative disorders: Ashwagandha. Cent Nerv Syst Agents Med Chem 10: 238-246.

2. Joshi KS, Bhonde R (2014) Insights from Ayurveda for translational stem cell research. J Ayurveda Integr Med 5: 4-10.

3. Chaudhari K, Murthy ARV (2014) Effect of rasayana on mental health-a review study. International Journal of Ayurveda and Alternative medicine 2: 1-7. 
4. Singh AK, Gupta AK, Manish Singh PK (2014) Rasayana therapy: A magic contribution of Ayurveda for healthy long life. Int J Res Ayurveda Pharm 5: 41-47.

5. Pradnya DD (2014) Role of rasayanchikitsa in promotion of health. Unique Journal of Ayurvedic and herbal medicines 2: 6-10.

6. Kumar V (2006) Potential medicinal plants for CNS disorders: an overview. Phytother Res 20: 1023-1035.

7. Kulkarni R, Girish KJ, Kumar A (2012) Nootropic herbs (Medhya Rasayana) in Ayurveda: An update. Pharmacogn Rev 6: 147-153.

8. Upadhyay AK, Kumar K, Kumar A, Mishra HS (2010) Tinospora cordifolia (Willd.) Hook. f. and Thoms. (Guduchi)-validation of the Ayurvedic pharmacology through experimental and clinical studies. International Journal of Ayurveda Research 1: 112-121.

9. Tiwari R, Tripathi JS, Gupta S, Reddy KRC (2011) Pharmaceutical and clinical studies on compound Ayurvedic formulation, Saraswata Churna. International Research Journal of Pharmacy 2: 77-84.

10. Patil RB, Gayal RR (2014) Rasayana A Multidimentional Therapy: A Review. International Ayurvedic Medical Journal 2: 433-439.

11. Doknark S, Mingmalairak S, Vattanajun A, Tantisira B, Tantisira MH (2014) Study of ameliorating effects of ethanolic extract of Centella asiatica on learning and memory deficit in animal models. J Med Assoc Thai 97 Suppl 2: S68-76.

12. Berrocal R, Vasudevaraju P, Indi SS, Sambasiva Rao KR, Rao KS (2014) In vitro evidence that an aqueous extract of Centella asiatica modulates a-synuclein aggregation dynamics. J Alzheimers Dis 39: 457-465

13. Prakash A, Kumar A (2013) Mitoprotective effect of Centella asiatica against aluminum-induced neurotoxicity in rats: possible relevance to its anti-oxidant and anti-apoptosis mechanism. Neurol Sci 34: 1403-1409.

14. Orhan IE (2012) Centella asiatica (L.) Urban: From Traditional Medicine to Modern Medicine with Neuroprotective Potential. Evid Based Complement Alternat Med 2012: 946259

15. Xu MF, Xiong YY, Liu JK, Qian JJ, Zhu L, et al. (2012) Asiatic acid, a pentacyclic triterpene in Centella asiatica, attenuates glutamate-induced cognitive deficits in mice and apoptosis in SH-SY5Y cells. Acta Pharmacol Sin 33: 578-587.

16. Luo L, Jin Y, Kim ID, Lee JK (2014) Glycyrrhizin suppresses HMGB1 inductions in the hippocampus and subsequent accumulation in serum of a kainic acidinduced seizure mouse model. Cell Mol Neurobiol 34: 987-997.

17. Chowdhury B, Bhattamisra SK, Das MC (2013) Anti-convulsant action and amelioration of oxidative stress by Glycyrrhiza glabra root extract in pentylenetetrazole- induced seizure in albino rats. Indian J Pharmacol 45: 40-43.

18. Kim SW, Jin Y, Shin JH, Kim ID, Lee HK, et al. (2012) Glycyrrhizic acid affords robust neuroprotection in the postischemic brain via anti-inflammatory effect by inhibiting HMGB1 phosphorylation and secretion. Neurobiol Dis 46: 147-156.

19. Zhu Z, Li C, Wang X, Yang Z, Chen J, et al. (2010) 2,2',4'-trihydroxychalcone from Glycyrrhiza glabra as a new specific BACE1 inhibitor efficiently ameliorates memory impairment in mice. J Neurochem 114: 374-385.

20. Cui YM, Ao MZ, Li W, Yu LJ (2008) Effect of glabridin from Glycyrrhiza glabra on learning and memory in mice. Planta Med 74: 377-380.

21. Yu XQ, Xue CC, Zhou ZW, Li CG, Du YM, et al. (2008) In vitro and in vivo neuroprotective effect and mechanisms of glabridin, a major active isoflavan from Glycyrrhiza glabra (licorice). Life Sci 82: 68-78.

22. Dhingra D, Sharma A (2006) Antidepressant-like activity of Glycyrrhiza glabra L. in mouse models of immobility tests. Prog Neuropsychopharmacol Biol Psychiatry 30: 449-454.

23. Parle M, Dhingra D, Kulkarni SK (2004) Memory-strengthening activity of Glycyrrhiza glabra in exteroceptive and interoceptive behavioral models. J Med Food 7: 462-466

24. Dhingra D, Parle M, Kulkarni SK (2004) Memory enhancing activity of Glycyrrhiza glabra in mice. J Ethnopharmacol 91: 361-365.

25. Kosaraju J, Chinni S, Roy PD, Kannan E, Antony AS, et al. (2014) Neuroprotective effect of Tinospora cordifolia ethanol extract on 6-hydroxy dopamine induced Parkinsonism. Indian J Pharmacol 46: 176-180.

26. Mishra R, Kaur G (2013) Aqueous ethanolic extract of Tinospora cordifolia as a potential candidate for differentiation based therapy of glioblastomas. PLoS One 8: e78764.

27. Dhingra D, Goyal PK (2008) Evidences for the Involvement of Monoaminergic and GABAergic Systems in Antidepressant-like Activity of Tinospora cordifolia in Mice. Indian J Pharm Sci 70: 761-767.

28. Rawal AK, Muddeshwar MG, Biswas SK (2004) Rubia cordifolia, Fagonia cretica linn and Tinospora cordifolia exert neuroprotection by modulating the antioxidant system in rat hippocampal slices subjected to oxygen glucose deprivation. BMC Complement Altern Med 4: 11.

29. Sethiya NK, Nahata A, Mishra SH, Dixit VK (2009) An update on Shankhpushpi, a cognition-boosting Ayurvedic medicine. Zhong Xi Yi Jie He Xue Bao 7: 1001-1022.

30. Nag G, De B (2008) Antioxidant and Acetylcholinesterase Inhibitory Properties of the Indian Medicinal Plant "Shankhapushpi" Used for Enhancing Memory Function. Journal of Complementary and Integrative Medicine 5: 1553-3840.

31. Bihaqi SW, Sharma M, Singh AP, Tiwari M (2009) Neuroprotective role of Convolvulus pluricaulis on aluminium induced neurotoxicity in rat brain. $J$ Ethnopharmacol 124: 409-415.

32. Verma S, Sinha R, Kumar P, Amin F, Jain J, et al. (2012) Study of Convolvulus pluricaulis for antioxidant and anticonvulsant activity. Cent Nerv Syst Agents Med Chem 12: 55-59.

33. Bihaqi SW, Singh AP, Tiwari M (2012) Supplementation of Convolvulus pluricaulis attenuates scopolamine-induced increased tau and amyloid precursor protein (Aî²PP) expression in rat brain. Indian J Pharmacol 44: 593-598.

34. Kumar N, Singh AK (2013) Medhya dravya in ayurveda-a critical review. International Ayurvedic Medical Journal 1: 1-4

35. Malavika S, Shivakumar, Kavita MB (2013) Medhaya Rasayana in an ageing brain. International Ayurvedic Medical Journal 1: 1-5.

36. Kuboyama T, Tohda C, Komatsu K (2005) Neuritic regeneration and synaptic reconstruction induced by withanolide $\mathrm{A}$. Br J Pharmacol 144: 961-971.

37. Kuboyama T, Tohda C, Zhao J, Nakamura N, Hattori M, et al. (2002) Axon- or dendrite-predominant outgrowth induced by constituents from Ashwagandha. Neuroreport 13: 1715-1720.

38. Stough C, Lloyd J, Clarke J, Downey LA, Hutchison CW, et al. (2001) The chronic effects of an extract of Bacopa monniera (Brahmi) on cognitive function in healthy human subjects. Psychopharmacology (Berl) 156: 481-484.

39. Holcomb LA, Dhanasekaran M, Hitt AR, Young KA, Riggs M, et al. (2006) Bacopa monniera extract reduces amyloid levels in PSAPP mice. J Alzheimers Dis 9: 243-251.

40. Saraf MK, Prabhakar S, Khanduja KL, Anand A (2011) Bacopa monniera Attenuates Scopolamine-Induced Impairment of Spatial Memory in Mice. Evid Based Complement Alternat Med 2011: 236186.

41. Dhingra D, Valecha R (2007) Evaluation of the antidepressant-like activity of Convolvulus pluricaulis choisy in the mouse forced swim and tail suspension tests. Med Sci Monit 13: BR155-161.

42. Rao SB, Chetana M, Uma Devi P (2005) Centella asiatica treatment during postnatal period enhances learning and memory in mice. Physiol Behav 86: 449-457.

43. Veerendra Kumar MH, Gupta YK (2002) Effect of different extracts of Centella asiatica on cognition and markers of oxidative stress in rats. J Ethnopharmacol 79: 253-260.

44. Veerendra Kumar MH, Gupta YK (2003) Effect of Centella asiatica on cognition and oxidative stress in an intracerebroventricular streptozotocin model of Alzheimer's disease in rats. Clin Exp Pharmacol Physiol 30: 336-342.

45. Gadahad MR, Rao M, Rao G (2008) Enhancement of hippocampal CA3 neuronal dendritic arborization by Centella asiatica (Linn) fresh leaf extract treatment in adult rats. J Chin Med Assoc 71: 6-13.

46. Bairy KL, Rao Y, Kumar KB (2004) Efficacy of Tinospora cordifolia on Learning and Memory in Healthy Volunteers: A Double-Blind, Randomized, Placebo Controlled Study. Iranian Journal of Pharmacology and Therapeutics 3: 57-60.

47. Agarwal A, Malini S, Bairy KL, Rao MS (2002) Effect of Tinospora Cordifolia on Learning and Memory in Normal and Memory Deficit Rats. Indian Journal of Pharmacology 34: 339-349.

48. Kulatunga RD, Dave AR, Baghel MS (2012) Clinical efficacy of Guduchyad Medhya Rasayana on Senile Memory Impairment. Ayu 33: 202-208.

49. Bhattacharya SK, Bhattacharya A, Sairam K, Ghoshal S (2000) Anxiolyticantidepressant activity of Withania somnifera glycowithanolides: an experimental study. Phytomedicine 7: 463-469. 
50. Sehgal N, Gupta A, Valli RK, Joshi SD, Mills JT, et al. (2012) Withania somnifera reverses Alzheimer's disease pathology by enhancing low-density lipoprotein receptor-related protein in liver. Proc Natl Acad Sci USA 109: 3510-3515.

51. Singh N (2006) Effect of Celastrus paniculatus on Learning, Memory and Serum biochemistry of Aging Albino Rats. Indian Journal of Gerontology 20: 310-316.

52. Lekha G, Kumar BP, Rao SN, Arockiasamy I, Mohan K (2010) Cognitive enhancement and Neuroprotective effect of Celastrus paniculatus Willd. seed oil (Jyothismati oil) on male Wistar rats. Journal of Pharmaceutical Science and Technology 2: 130-138.
53. Ansari MN, Bhandari U, Islam F, Tripathi CD (2008) Evaluation of antioxidant and neuroprotective effect of ethanolic extract of Embelia ribes Burm in focal cerebral ischemia/reperfusion induced oxidative stress in rats. Fundamental \& Clinical Pharmacology 22: 305-314.

54. Thippeswamy BS, Nagakannan P, Shivasharan BD, Mahendran S, Veerapur VP, et al. (2011) Protective effect of embelin from Embelia ribes Burm against transient global ischemia-induced brain damage in rats. Neurotox Res 20: 379-386.

55. Chandre R, Upadhyay BN, Murthy KH (2011) Clinical evaluation of Kushmanda Ghrita in the management of depressive illness. Ayu 32: 230-233. 